\title{
プロピレンおよびアニリンの塩化パラジウム 錯化合物の研究*
}

\author{
中村 政 宣** 郡司 孝 紀 **
}

Studies on Propylene-palladium Chloride and Aniline-palladium Chloride Complex*

by Masanobu Nakamura** and Köki Gunji**

\begin{abstract}
Summary : This is to describe the formation and properties of a complex obtained by reaction of propylene with palladium (II) chloride in non-polor solvents such as $n$-heptane, carbon tetrachloride and p-xylene.

The isolated complex was assumed to be propylene-palladium (II) chloride complex as judged from $\mathrm{X}$-ray diffraction, infrared spectra and gaschromatographic analysis of gaseous components which evolved by its thermal decomposition.

The complex behaves like a Zeise's salt, i.e., hydrolysis of the complex gives acetone and reaction with sodium acetate in acetic acid gives isopropenylacetate.

A stable yellow-colored complex was formed from anilin and palladium (II) chloride.

Infrared spectra of this stable complex is compared with that of anilin and benzonitril-palladium (II) chloride complex.
\end{abstract}

\section{1 緒 言}

プロピレンからアセトンの合成反応は，オレフィンから相当 するカルボニル化合物合成法として J. Smidt ら”によって研 究され，エチレンからアセトアルデヒドの製造法と同様すでに Höchst-Wacker 法として工業化されている。エチレンからア セトアルデヒドの合成反応についてはかなり詳細にわたり，2， 3 の研究 ${ }^{2} か ゙$ 行なわれており，その反応機構もほは明らかにさ れている。

それらの研究結果によると，ての反応過程にわいて，エチレ ンはまず触媒である㙁化パラシウムと錯化合物をつくるものと 考えられている。

以上のととから，J.Smidt らの行なった，オレフィンの直接 酸化によるカルボニル化合物の製法が反応中間体として,オレ フィンー塩化パラシウム錯化合物を経るという考えに基づくな らば,プロピレンからアセトンの生成過程においても, プロピ レンー塩化パラジウム錯化合物か泩成するはずである。

ここでオレフィン-白金属金属塩錯化合物の研究であるが,こ

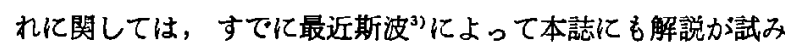
られているし，その他 2,3 の総説“もある。とれらの解説にも 見られるように，プロピレン一塩化白金錯化合物については, Zeise 㙁"゙してるかなり古くから知られており，また比較的 近年, J. Chatt らののオレフィン-塩化白金錯化合物に関する 赤外線吸収スペクトルによる研究もあるが，プロピレンー塩化 パラシウム錯化合物に関しては，いまだ直接分離できる形で得

* 昭和 37 年 11 月 24 日受理

** 大協石油株式会社 研究所 Daikyo Oil Co. Ltd., Research Laboratories
られていない。

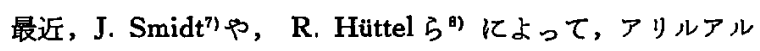
コール, アリルクロリドなどと, 塭化パラジウムの反応加ら， 黄色のアリルー塩化パラジウム錯化合物 $\left(\mathrm{C}_{3} \mathrm{H}_{5} \mathrm{PdCl}\right)_{2}$ が単離 された。

さらに、とのアリルー塩化パラジウム錯化合物については, C. Dehn ら"によって, N.M.R. による研究加ら錯体の構造に ついても検討されている。

しかし，このアリル-塩化パラジウム錯化合物は加水分解に より，アセトンを与えずアクロレインを生成する。てのてと は,プロピレンからアセトンの合成反応について, 反応中間体 として考えられろ鍇化合物には相当しない。

そこでわれわれは，先に(10)エチレン一塩化パラジウ人錯化合 物について, エチレンと塩化パラジウムの極性および無極性溶 媒中における直接反応より観察を試みたと同様な実験を，今回 はプロピレンと塩化パラジウムの直接反応について検討した。 また,アニリンと塩化パラジウムの反応から, きわめて安定な アニリンー塩化パラジウム錯化合物が得られたととについてあ わせ鞎告する。

\section{2 試料および分析方法}

ほぼ前報と同様の試料および分析方法によった。

2.1 試料

(1) プロピレン：市販高純度品を使用，ガスクロマトグラ フ分析の結果, 純度 $99.5 \%$ であった。

(2) 塩化パラジウム：市販特級品を使用， $\mathrm{X}$ 線分析の結 果，不純物と思われる回折線は全く諗められなかった。

（3）醀酸ナトリウム：市眅特級品，然水物をそのまま使用 
した。

（4）反応に使用した各種溶媒：前報と同様，常法により精 製、精留後脱水乾燥，屈折率が文献值と一致，ガスクロマトグ ラフ分析により純品であると琵められたものを使用した。

\section{2 分析方法}

各反応における，ガス状および液状物質については，ガスク ロマトグラフと赤外線吸収スペクトルで, 固体物質について は線回折および赤外線吸収スペクトルを用い分析を行なっ た。

各機器についての測定操作条件を以下に記す。

\subsection{1 ガスクロマトグラフ分析}

Perkin-Elmer 社製, Triple Stage Vapor Fractometer Model 188 で分析を行なった。

測定操作条件を表 1 亿示す。

表 I ガスクロマトグラフ分析測定操作条件

\begin{tabular}{|c|c|c|c|}
\hline & ガス状物質 & 液 状 & 物 䓄 \\
\hline Column & $\begin{array}{c}\text { Perkin-Elmer } \\
\text { Column } V^{\prime}\end{array}$ & $\begin{array}{l}\text { Perkin-Elmer } \\
\text { Column } A^{*}\end{array}$ & $\begin{array}{l}\text { Perkin-Elmer } \\
\text { Column } W^{* *}\end{array}$ \\
\hline$\underset{\left({ }^{\circ} \mathrm{C}\right)}{\text { Column temp. }}$ & $\underset{\left(18^{\circ} \mathrm{C}\right)}{\text { Room temp. }}$ & 100 & 100 \\
\hline Carrier gas & $\mathrm{He}$ & $\mathrm{He}$ & $\mathrm{He}$ \\
\hline $\begin{array}{l}\text { Flow rate } \\
\text { (cc/min) }\end{array}$ & 80 & 80 & 67 \\
\hline
\end{tabular}

\subsection{2 $\mathrm{X}$ 楾回折}

X線回折計 (Geiger Flex 理学電機製) で対陰㮀に は $\mathrm{CuK}_{\alpha}(\mathrm{Ni} フ$ ィルター) を用い, $32 \mathrm{kV}, 18 \mathrm{~mA}$, 走 查速度 $2 \%$ min で $2 \theta=5 \sim 70^{\circ}$ の䇺囲にわたって測定 した。

2.2.3 赤外線吸収スペクトル

Shimadzu 赤外分光光度計 IR-27 B 型により, $\mathrm{NaCl}$ プリズムで, 液体試料はサンドウィッチ法, 固 体陚料については， $\mathrm{KBr}$ 錠倣法により測定した。

\section{3 ブロピレンと塩化ハララジウムの無㮒性溶 媒中における直接反店}

\section{1 反応状況の镜察}

前報で，エテレンと塩化パラジウムの面接反応を武みたと全 く同様の方法で反応を行ない観察した。

すなわち，塩化パラシウム約 $4.0 \mathrm{~g}$ を無極性溶媒 $60 \mathrm{cc}$ 中に 照濁させ、マグネチックスターラーでかきまぜながら室温 (18 ${ }^{\circ} \mathrm{C}$ 前後)で過剩のプロピレンを通し反応を行なっだ。

反応開始後 $30 \mathrm{~min}$ ぐらいで黄色物貝の生成が認められた。 さらに 7 8hr プロピレンを通したのち，口別するととによ り，黄カッ色の錯化合物と思われる生成物を単離した（以下， ての反応で単離された黄色物質を，P.P.N.制注1) と略記する)。

ロ液について，ガスクロマトグラフ分析を行なったがなんら 変化は認められなかった。

各溶媒について行なった反応条件を表 2 に示す。

脚注” P.P.N. の略記は,ブロビレンとバラジウムクロリドの無極性溶 媒中の反応より単離された物質を指すため, プロビレン, パラジ ウムクロリド，無極性溶媒の頭文字をとり表現した。
表 2 ブロビレンと塩化ハシラジウムの重極性溶媒中に おける反応条件

\begin{tabular}{|c|c|c|c|}
\hline 実臨番号 & 反応使用溶媒 & $\begin{array}{c}\text { 反応温度 } \\
\left({ }^{\circ} \mathrm{C}\right)\end{array}$ & $\begin{array}{c}\text { 反応時間 } \\
(\mathrm{hr})\end{array}$ \\
\hline CSP-1 & n-ヘプタン & 18 & 6 \\
\hline CSP-2 & ベンゼン & 20 & 6 \\
\hline CSP-3 & 四塩化炭素 & 18 & 7 \\
\hline $\mathrm{CSP}-4$ & シクロヘキサン & 18 & 7 \\
\hline CSP-5 & $p-キ シ v ン$ & 15 & 10 \\
\hline CSP-6 & n-ヘ ブ & 18 & 17 \\
\hline
\end{tabular}

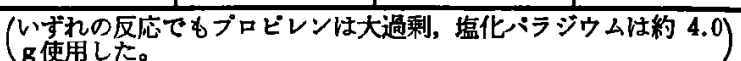

\section{2 反応生成物 (P.P.N.) の検索}

以上の反応で得られた黄カッ色の生成物 (P.P.N.) を減圧乾 燥後, 次に示す実験より，ての物質の性状について検討した。

\subsubsection{P.P.N. の X 線回折}

各溶媒について行なった反応から単離されたそれぞれのP. P.N. について X 線回折を行なったとてら，いずれも同様の $\mathrm{X}$ 線回折図が得られた。

得られだ結果の一つを図 1 亿示す。

$\mathrm{X}$ 線回折には，塩化パラジウムに相当する回折線は認められ なかった。

P.P.N. を密センして, デシケーター中に保存, 約 6 力月経 過後の式料について観察すると，色彩は黄カッ色加茶カッ色

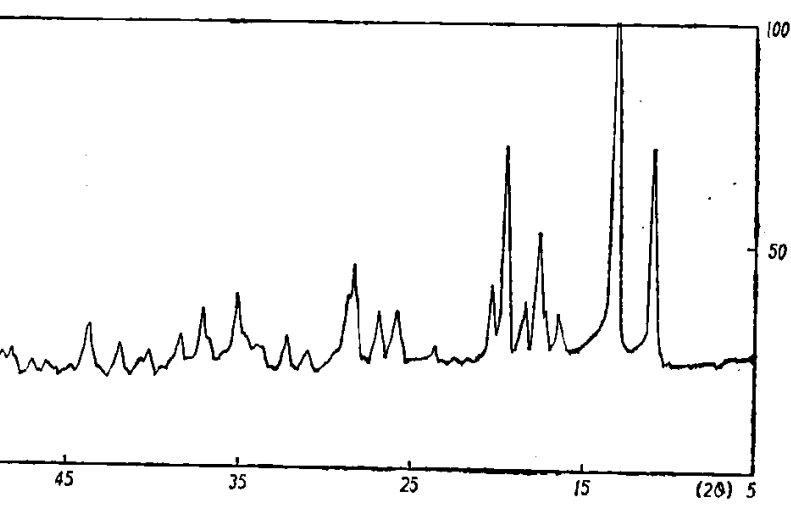

图 1 P.P.N.の X線回折図

に変化しているが, X線回折の結果, 塩化パラジゥムに相当す ろ回折線と, 試料調製直後のX線回折で示されたと同様の回折 線が認められるX線図が得られた。

以上のととから，P.P.N. は常温で，かなり安定な物䨘であ ろが，しだいに分解して，塩化パラジムになるものと考元ら れた。

\subsubsection{P.P.N. の熱分解}

少量の武料 (P.P.N.) を封管中に入れ，徐々に加熱しなが ら，生成する分解ガスをガスクロマトグラフ分析した。

40 50 $\mathrm{C}$ 付近まで加熱すると分解ガスの発生か認められ， とれはプロピレンと同定された。

さらに $90^{\circ} \mathrm{C}$ 付近まで加熱すると分解ガスの発生に伴い液状 物の生成が認められた。

$90^{\circ} \mathrm{C}$ 付近まで加熱したときの生成ガスについて，ガスクロ マトグラフ分析を行なった結果，大部分はプロピレンであり， 
その他その保持時間から，おそらく $\mathrm{C}_{0}$ オレフィン類に相当す ると思われる三つの成分が少量検出された。

加熱後 $\left(96^{\circ} \mathrm{C}\right.$ まで)の武料についてX線回折を行なったとと ろ，塩化パラシウムのX線回折図が得られた。

なお，との回折図には，パラジウムに相当する回折線も恝め られた。

武料 (P.P.N.) の熱分解で生成する生成ガス中に，プロピレ ンのほか, 少量の三つの成分が検出されたととについては，前 報昼でエチレンと塭化パラシウムの気相反応を武みた際に，ブ テン-1,ブテン-2 (cis, trans) が桧出されたととから予想され たととであったが，念のため同様の気相反応をプロピ レンと塩化パラジゥムについて $70^{\circ} \mathrm{C}$ で行なった。 生成ガスについてガスクロマトグラフ分析を行なっ たとてろ，検出された成分はすべ，試料 (P.P.N.) の熱分解生成ガスで認められたものと保持時間および 各成分生成比（面積比）が一致した。

3.2.3 P.P.N. の赤外楾吸収スペクトル

P.P.N. の赤外線吸収スペクトルを $\mathrm{KBr}$ 錠剤法に より测定した。結果を图 2 亿示す。

得られた P.P.N. の赤外線吸収スぺクトル図を， J. Chattらにより測定され，示されている，プロピレ ン一塩化白金錯化合物 $\left(\mathrm{C}_{3} \mathrm{H}_{6} \mathrm{PtCl}_{2}\right)_{2}$ の赤外線吸収スペ クトル吸収帯波数表と比較した。

$3,000 \mathrm{~cm}^{-1}$ 付近の吸收寡については, J. Chatt $ら^{6)}$ がての領域に LiF プリズムを使用して則定したよう な満足な結果は得られなかったが，そのはかの吸収带 $\left(1,600 \mathrm{~cm}^{-1}\right.$ 以下) については，十分比較検討するこ とができた。

J. Chatt らは, プロピレン-塩化白金錯化合物の赤 外線吸収スペクトルにおいて, $1,504 \mathrm{~cm}^{-1}$ の強い吸収 带をプロピレンの $\mathrm{C}=\mathrm{C}$ によるものとして㷌属してい る。

とれは，プロピレンが白金に配位することにより， 通常の $\mathrm{C}=\mathrm{C}$ 伸縮振動供づく财收帯と比較して約 $143 \mathrm{~cm}^{-1}$ 低波数に移動したものと解积している。

この, J. Chatt らの見解にしたがうならば，P.P.N. の赤外線吸収スペクトルにおける $1,530 \mathrm{~cm}^{-1}$ にある 強い吸収帯は，おそらく埕=c と考えられる。

そのほか各吸收带（vc=c に基づくと解釈した吸収 帯をのぞいて)について見ると，J. Chatt らのによ。 て示されていろ,プロピレン-塩化白金錯化合物 $\left(\mathrm{C}_{3} \mathrm{H}_{6}\right.$ $\left.\mathrm{PtCl}_{2}\right)_{2}$ の级収帯とよく一致している。

\subsubsection{P.P.N. の加水分解}

P.P.N. 約 $3.0 \mathrm{~g}$ を水 $30 \mathrm{cc}$ 中に入れると，ただち に黒変して分解したてとか認められる。

約 $1 \mathrm{hr}$ 室温でかきまぜながら反応させ，反応後口 別，口液はガスクロマトグラフ分析を行ない，口過残 サについてはX線回折を行なった。

ガスクロマトグラフ分析の結果, 生成物としてアセ トンが検出され，X線回折では，口過残サがパラジ ムであるととが明らかにされた。

X楾回折結果を图 3 亿示す。

\subsubsection{P.P.N.と酢酸ナトリウムの水酢酸溶媒中における} 反応

P.P.N. 約 $4.0 \mathrm{~g}$ と酶酸ナトリウム約 $4.0 \mathrm{~g}$ を水酢酸 $60 \mathrm{cc}$ 中 に入れ，室温で約 $8 \mathrm{hr}$ かきまぜながら反応させた。

反応後口別, 口液はガスクロマトグラフ分析, 口過残サは乾

煤後X線回折を行なった。

その結果，㖡加生成物として，イソプロペニルアセテー トが検出された。はお，てのロ液のガスクロマトグラムには未 確認成分か一つ，ほぼ等量（面積比）認められた。

反応残サはX線回折より，パラジムと塩化ナトリウムであ

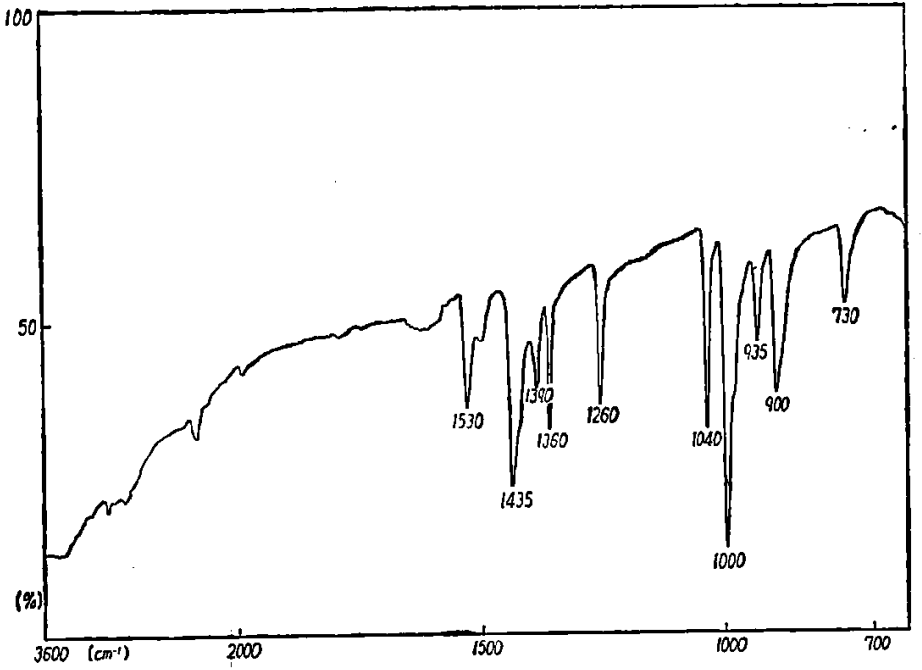

图 2 P.P.N.の赤外線吸收スペクトル図

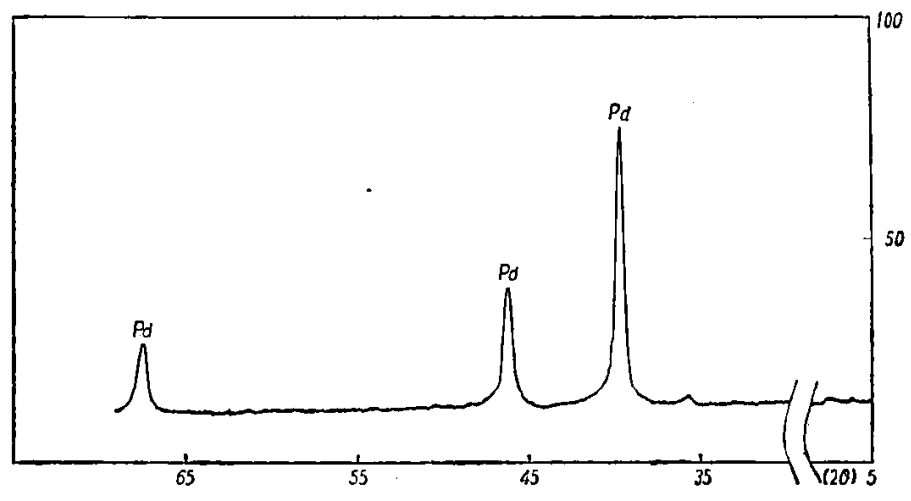

図 3 P.P.N. 加水分解反応後口過残サのX線回折図

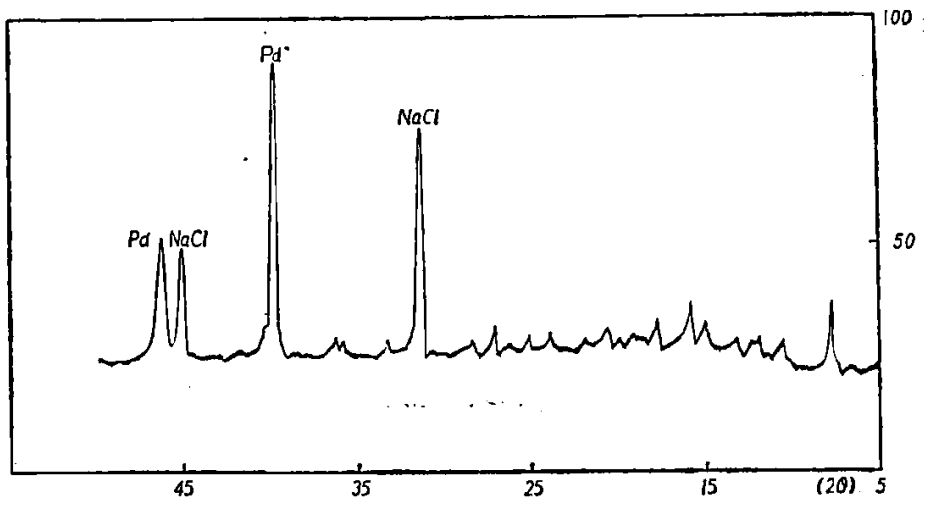

因 4 P.P.N. と酭酸ソーダの水酭酸中での反応後口過残サX線回折図 
った。

X線回折図を図 4 亿示す。

\subsection{P.P.N. に関する $2 ， 3 の$ 考察}

以上の実験から，プロピレンと塩化パラジウムの無極性溶媒 中におけら反応より単㒕された黄カッ色物質 (P.P.N.)は，は ばプロピレンと塩化パラジウムの錯化合物と推定された。

すなわち, 3.2.1で行なった, P.P.N.のX 線回折の結果に は，塩化パラジウムに相当する回折線は認められず，またとの 反応で使用した溶媒は反応後にわいてる変化しなかったてとな どから，P.P.N. はプロピレンと塩化パラジゥムの反応で生成 した物質と考元られ，3.2.2 の実験で P.P.N. の組成は，ほば プロピレンと塩化パラジウムからなる物質と推定された。

P.P.N. について測定した赤外線吸収スペクトルの各吸収带 は，J. Chatt らのによって示されている，プロピレン-塩化白 金錯化合物 $\left(\mathrm{C}_{3} \mathrm{H}_{6} \mathrm{PtCl}_{2}\right)_{2}$ の赤外線吸収スペクトルの各吸収帯 波数々比較してみると，白金，パラジウムの質量数の差による ためと解釈できる程度の吸収帯移動を鿄めるならば, P.P.N.上 プロピレン-塩化白金錯化合物 $\left(\mathrm{C}_{3} \mathrm{H}_{6} \mathrm{PtCl}_{2}\right)_{2}$ の各吸収帯は上 く一致する結果が得られた。

3.2 .4 および 3.2 .5 における各反応では, P.P.N. が加水分 解でパラジウムに変化して,アセトン定生成, また, 酷酸ナト リウムと氷釄酸溶媒中での反応では，イソプロペニルアセテー 忧を生成するなど，Zeise 塩と同様の挙動を示すとと から，同しような Type に属するものとる考えられ る。

ととで,J. Smidt ら"により開発された，オレフィ ンからカルボニル化合物合成反応についてであるが, この反応機構に関しても，最近かなり詳細にわたって 2,3 の研究がなされてはいるが，反応中間体としての オレフィンー塩化パラジウム錯体の生成は，あくまで J.S. Anderson ら ${ }^{11)}$ の実酫に基づく推論であり，反応 中にオレフィンー塩化パラジウム錯化合物の生成を直 接証明した実験事実がないため，P.P.N. がただちに プロピレンからアセトンの合成反応にわける，反応中 間体に相当する錯化合物であるとは言及できない。

しかしながら，P.P.N. は前報で得られたエチレ ン一塩化パラジゥム錯化合物と同梯の反応方式で得ら れ，しかも，加水分解反応や水醀酸溶媒中にわける醈 酸ナトリゥムの反応などで類似の性質を示すとと，お よび従来多くのオレフィンー塩化パラジウム錯化合物 が単離されているにもかかからず,プロピレンと塩化 パラジウムの鍇化合物については報告が見られなかっ たととから，今回の実験で，2，3の興味ある事実の認 められたととは，この方面に関する研究に一つの知見 を与えるものと思われる。

\section{4.アニリンट塩化パラジウムの反応}

アニリン $60 \mathrm{cc}$ 中に塩化パラジウム約 $4.0 \mathrm{~g}$ をいれ

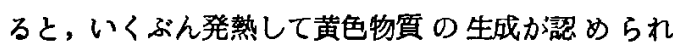
た。

さらに・1 hr ほどかきまぜながら反応を続けた後， 口別するととによりきれれな黄色物質（以下 A.P.
と略記する)を単離することができた。

A.P.について X 線回折および赤外線吸収スペクトルを湘定 した。

\subsection{A.P. の $\mathrm{X}$ 線回折}

A.P. のX線回折図を図 5 亿示す。

$\mathrm{X}$ 線回折図には，塩化パラシ்ムに相当する回折線は隐めら れない。

また，A.P. は約 4 力月経過しても，黄色の色彩もおとろ党 ることなくふふたたび测定したX線回折結果は，調製直後と全 く同様の回折図形な示したととから，きわめて安定な物質であ るととがかかた。

4.2 A.P. の赤外線吸収スベクトル

A.P. の赤外線吸収スペクトルを $\mathrm{KBr}$ 錠剤法により湘定し た結果を图 6 亿示す。

得られた A.P. の赤外線吸収スペクトルをアニリンの赤外線 财収スペクトルと比較検討した。

A.P. の赤外線吸収スペクトルにおける $3,200 \mathrm{~cm}^{-1}$ 付近と $1,600 \mathrm{~cm}^{-1}$ の忣収帯は, アニリンの $3,400 \mathrm{~cm}^{-1}$ の $\nu_{\mathrm{N}-\mathrm{H}}$, $1,620 \mathrm{~cm}^{-1}$ の $\delta_{\mathrm{NH}_{2}}$ 吸収帯が, アニリンが塩化パラジムに配 位したため低波数に移動したものと思われる。

これは，一般に N-H の振動に基づく吸収带が金属イオンと 配位化合物をつくった場合、これら $\mathrm{N}-\mathrm{H}$ に基つく吸収带は低

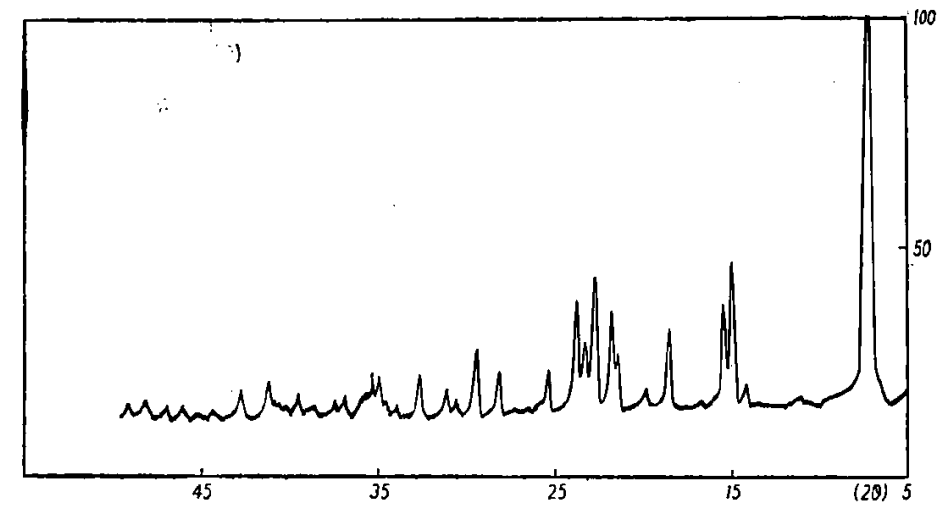

因 5 A.P.のX線回折因

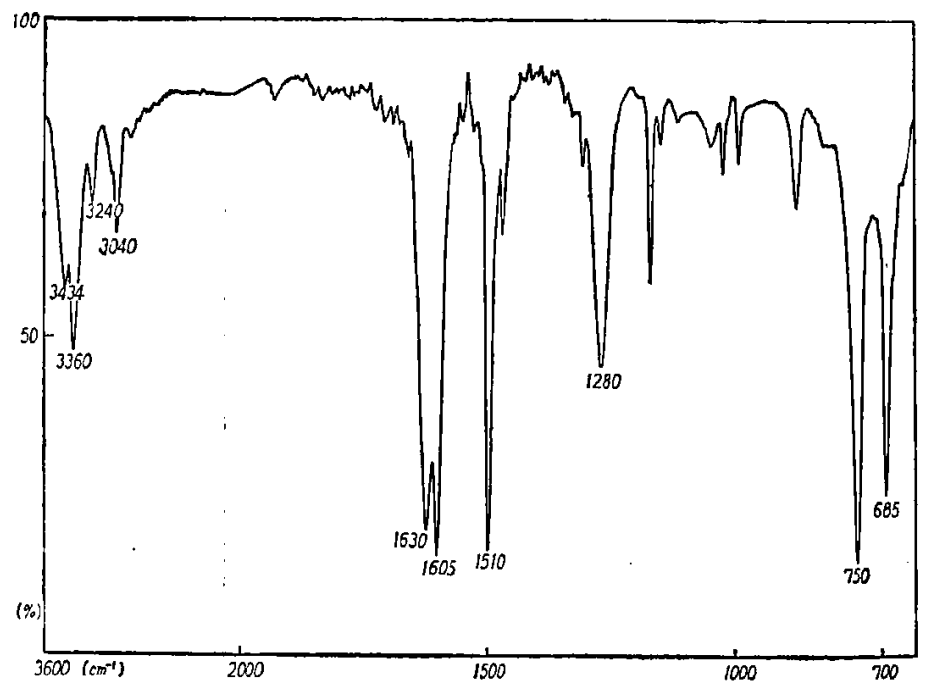

因 6-1 フニリンの赤外線吸収スベクトル図 


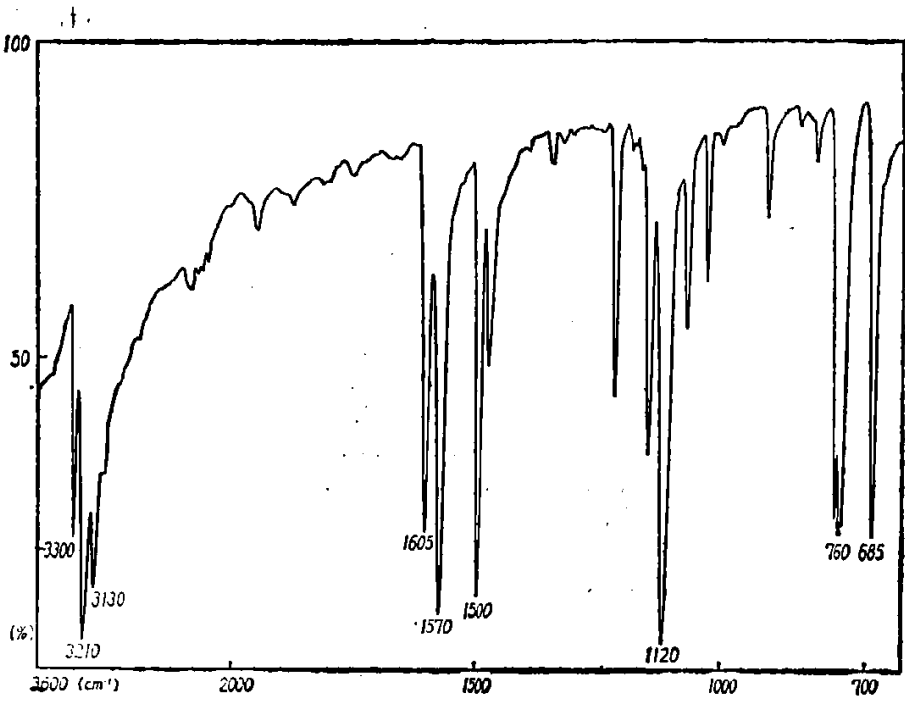

図 6-2 A.P. の赤外線吸収スペクトル図
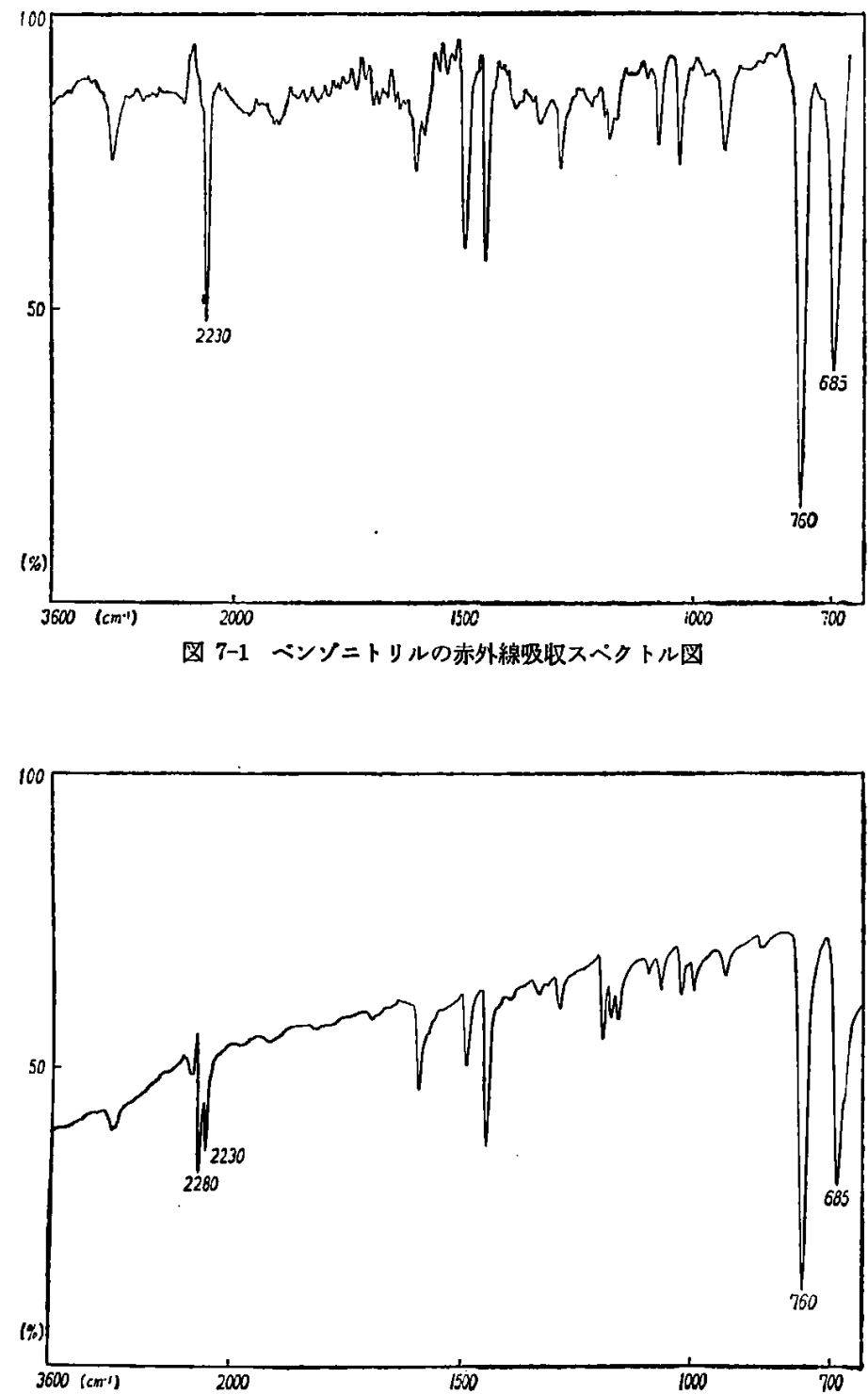

図 7-2 ペンソニトリルー塩化パラジウム錯化合物の赤外線级收スペクトル図
波数に移動するといわれているととに基づき解秎し た。

$1,500 \mathrm{~cm}^{-1}$ のフェニル基，および 750, $690 \mathrm{~cm}^{-1}$ の フェニルモノ置換特性忣収带は，アニリンとほとんど 同一のところに観测された。

たた，A.P. において，750 $\mathrm{cm}^{-1}$ の吸收带が3本に 分枝しているととについては，

（1）アニリンの赤外図と比較して，とくに移動し たと考えられる吸収带がアニリンの赤外線吸収スペク トルに想められない。

（2）ベンゾニトリル-塩化 パラジウム錯化合物 (M.S. Kharasch の方法 ${ }^{12)}$ で調製) とベンソニトリル の赤外線吸収スペクトルを測定比較したところ，両者 の吸収帯は一致, $760 \mathrm{~cm}^{-1}$ のフェニルモ，置換吸収 带は分枝するととがなかった。

得られだ赤外線吸收スペクトル図を図 7 亿示す。

(1),(2)より，アニリンと塩化パラジウムか錯化 合物をつくるととで生じた結合に基づく吸収帯が重な ったものとも考えられる。

とてで,ベンゾニトリルー塩化 パラシウム錯化合物 在比較の対象としたことは，芳香族化合物一金属（临） 錯化合物に関する赤外線吸収スペクトルについて十分 な知見が示されていないため，よく知られている錯化 合物の一つとして選んだ。

ベンゾニトリルー塩化パラジウム鍇化合物の赤外吸 収スペクトルでベンソニトリルの $2,230 \mathrm{~cm}^{-1}$ にある $\mathrm{C} \equiv \mathrm{N}$ に基づく吸收带が 2 本に分枝することは興味あ ることだが今回は詳紲について検討しなかった。

A.P. 各四収带について，十分な帰属は行なわなか ったが，以上の結果で，A.P.がアニリンー塩化パラシ ウム錯化合物であることが推定された。

さらに，次の測定でアニリン-塭化パラジウム錯化 合物は，ほぼ $\left(\mathrm{C}_{6} \mathrm{H}_{5} \mathrm{NH}_{2}\right)_{2} \cdot \mathrm{PdCl}_{2}$ の二量体を形成す るものと考えられた。

すなわち，正しくはかっった䈒化パラジゥム $1.858 \mathrm{~g}$ $(0.0105 \mathrm{~g} \mathrm{~mol})$ を，アニリン $40 \mathrm{cc}$ 中でかきまぜなが ら室温 $\left(18^{\circ} \mathrm{C}\right)$ で $6 \mathrm{hr}$ 反応させ，単離された物質を エチルエーテルでよく洗浄した。

これで A.P. $3.845 \mathrm{~g}$ を得た。

重量増加 (3.845 g - $1.858 \mathrm{~g}) 1.987 \mathrm{~g}$ はアニリン

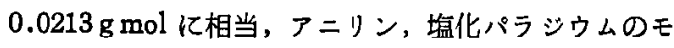
ル比は約 2:1 であった。

以上, アニリンと塩化パラジゥムの反応で，きわめ て安定なアニリンー塩化パラシウム錯化合物 $\left(\mathrm{C}_{6} \mathrm{H}_{5}\right.$ $\left.\mathrm{NH}_{2}\right)_{2} \cdot \mathrm{PdCl}_{2}$ の生成するてとがわかった。

\section{5 総括}

（1）プロピレンと塩化パラジウムの反応を無極性 溶媒中で行なったところ，黄カッ色物質（本文中， P.P.N. と略記) が単離された。

P.P.N. は X 線回折, 赤外線吸収スペクトルおよび 熱分解による生成ガス組成のガスクロマトグラフ分析 
などから、ほぽプロピレンー盐化パラジウム錯化合物と推定さ れた。

さらに, P.P.N. について加水分解反応在行なったとてろア セトンの生成が，また氷醀酸溶媒中で酢酸ナトリウムと反応さ せたとてろイソプロペニルアセテートの生成が認められるな ど、Zeise 塩と同样な挙動を示すととから，同しような Type の錯化合物化属するるのではないかと考光られた。

（2）アニリンと㙁化パラジウムの反応から，きわめて安定 な,きれいな黄色のアニリン一塩化パラジウム錯化合物 $\left(\mathrm{C}_{6} \mathrm{H}_{5}\right.$ $\left.\mathrm{NH}_{2}\right)_{2} \cdot \mathrm{PdCl}_{2}$ が単離された。

アニリンと塩化パラジウムの反応状況および反応生成物につ いてX線回折と赤外線吸収スペクトルを測定，得られた結果よ り生成物について梌索した推移について述へた。

謝 辞

本研究の発表を辟可されだ, 当社副社長大坪太計椎, 種 々御助言いただいた当研究所所長吉田信一郎, 調查室長清
水信一わよび実験汇嗳助下さった大協和石油化学（株）川! 北邦男の諸氏に深く謝意を表します。

\section{文献}

1) Smidt, J., et al., Angew. Chem., 71, 176 (1959). Deutsch $1,059,453$ (1959), Deutsch 1,061,767 (1959).

2) 斯波, 桐生, 第 4 回石油学会研究発表会諈演

Smidt, J., et al., Angew. Chem., 74, 93 (1962).

Moiseev, I.I., et al., Doklady Akad. Nauk S.S.S.R., 133, 377 (1960).

3）斯波, 石油誌, 5, 342 (1962).

4) 守谷, “最新の化学とその応用”, 第 13 集, 150 (1961) 槙書店.

5) Zeise W.C., Pogg. Ann., 21, 497 (1831).

6) Chatt, J. Duncanson, L.A., J. Chem. Soc., 1953, 2939.

7) Smidt, J. Hafner, W., Angew. Chem., 71, 284 (1959).

8) Huttelt, R., et al., ibid.. 11, 456 (1959); Chem. Ber., 94, 776 (1961).

9) Drhn, C., Chien, C., J. Am. Chem. Soc., 82, 4429 (1960).

10) 中村, 郡司, 石油誌, 5, 720 (1962).

11) Anderson, J.S., J. Chem. Soc., 1934, 971.

12) Kharasch, M.S., et, al., J. Am. Chem. Soc., 60, 882 (1938). 